\title{
Isolation and Characterization of Potential Bacteriocin Producing Lactic Acid Bacteria From Fermented Food Products
}

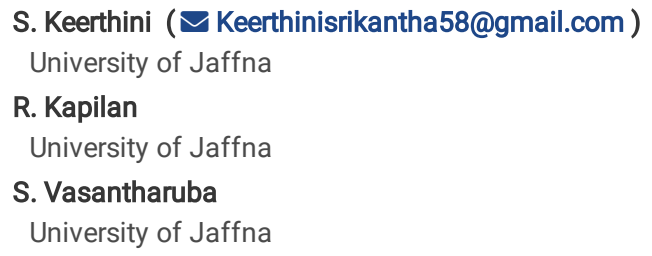

\section{Research Article}

Keywords: Antibacterial activity, bacteriocin, fermented food products, food spoilage organisms, LAB

Posted Date: August 24th, 2021

DOI: https://doi.org/10.21203/rs.3.rs-815679/v1

License: () (i) This work is licensed under a Creative Commons Attribution 4.0 International License. Read Full License 


\section{Abstract}

\section{Background}

Probiotic, Lactic Acid Bacteria (LAB) are consumed by human through the traditional food products for several decades due to their beneficial health effects. LAB is Gram positive, non motile bacteria that produce antimicrobial peptides for their defense mechanism. Among the antimicrobial peptides, Bacteriocins are widely investigated because of their possible utilization in food sector especially food security actions, where bacteriocin kills or inhibits the growth of other bacteria. Usage of metabolic products of $L A B$ and $L A B$ are generally recognized as safe. Therefore, this study was aimed to isolate $L A B$ species that produce bacteriocin showing wide spectrum antibacterial activity.

\section{Results}

Lactic acid bacteria were isolated from yoghurt, curd, dosa batter, idli batter and soaked and ground rice batter using (De Man, Rogosa and Sharpe agar) MRS agar and incubated at room temperature $\left(30 \pm 2^{\circ} \mathrm{C}\right)$ for $24-72 \mathrm{~h}$ aerobically and anaerobically. When agar well diffusion method was employed to detect the antibacterial activity of the twenty five isolates against food spoilage organisms (Enterococcus faecalis, Staphylococcus aureus, Pseudomonas aeruginosa, E.coli, Klebsiella pneumoniae, Serratia marcescens, Salmonella sp., Proteus sp., Micrococcus sp., and Bacillus sp.,). Three bacterial species showing broad spectrum of antibacterial activity, were identified and characterized by biochemical and molecular methods. The wide spectrum antibacterial bacterial species were identified as Lactobacillus reuteri AF182723 isolated from curd, Lactobacillus rhamnosus AY299488 isolated from rice batter and Lactobacillus acidophilus AF182726 isolated from yoghurt. Among all the isolates, Lactobacillus reuteri AF182723 showed significant wide spectrum antibacterial activity against diverse Gram positive and Gram negative bacterial species.

\section{Conclusion}

The production of bacteriocin from Lactobacillus reuteri AF182723 and incorporating it in the food would inhibit the food spoilage organisms. Usage of this bacteriocin at appropriate concentration in food needs to be studied further.

\section{Background}

Lactic acid bacteria (LAB) are long been consumed by people in several fermented foods. Lactic acid bacteria display numerous antimicrobial activities due to the production of organic acids, bacteriocins and antifungal peptides. Bacteriocins are antibacterial proteins and posttranslational modified peptides produced by bacteria that have a bacteriocidal or bacteriostatic effect on other bacterial species (Cleveland et al., 2001). Bacteriocins are generally recognized as "natural" compounds that can influence the safety and quality of foods. Since food safety has become an increasingly important international concern, the application of bacteriocin from lactic acid bacteria, which target food pathogens without toxic or other adverse effects, has received great attention (Cleveland et al., 2001). Though Bacteriocins could be categorized as antibiotics; they are not produced during the primary phase of growth. Bacteriocins from $L A B$ are peptides with antimicrobial activity synthesized by ribosomes as part of their defense mechanism and potential to cover a very broad field of application, including both the food industry and the medical sector (Vuyst and Leroy, 2007). Most of LAB bacteriocins are small ( $<10 \mathrm{kDa})$ cationic, heat-stable, amphiphilic and membrane permeabilizing peptides. Nowadays usage of bacteriocins in food industry has been extensively investigated (Zacharof and Lovittb, 2012). Bacteriocins produced by LAB have the potential to cover a very broad field of application in food industry. Usage of LAB and their metabolic products generally considered as safe (Zacharof and Lovittb, 2012). Therefore, this study was aimed to isolate of LAB from fermented food products and to screen and identify the bacterial species showing wide spectrum antibacterial activity.

\section{Results}

\section{Isolation of lactic acid bacteria from fermented food products}

Lactic acid bacteria (LAB) were isolated by using MRS agar containing bromocresol green as an indicator for acid formation. Bromocresol green will change to yellow colour in acidic condition (Fhoula et al., 2013). Therefore, colonies with yellow colour zone were randomly picked $24-72 \mathrm{~h}$ intervals and streaked repeatedly on MRS agar. Resulted pure colonies were streaked on MRS agar substituted with $1 \%$ cycloheximide to confirm the presence of yeast. Twenty-five bacterial isolates were obtained from the fermented food products such as curd, yoghurt, rice batter, dosa batter and idli batter by using of MRS agar plate substituted with $1 \%$ cycloheximide were gram positive and catalase negative. Therefore, these 25 isolates were considered as $L A B$ bacteria. From the experiment, four LAB isolates were isolated from curd, five from yoghurt, five from rice batter, six from dosa batter and five from idli batter.

\section{Detection of antibacterial activity of isolated lactic acid bacteria}

Results of the antibacterial activity study of the isolated LAB are explained in Table 1. The potential three bacterial genera which inhibited the highest number of food spoilage organisms were selected for further studies. 
Table 1

Average inhibitory zone of isolated lactic acid bacteria from fermented food products

\begin{tabular}{|c|c|c|c|c|c|c|c|c|c|c|}
\hline Isolate & $\begin{array}{l}\text { Staphylococcus } \\
\text { aureus }\end{array}$ & $\begin{array}{l}\text { Enterococcus } \\
\text { faecalis }\end{array}$ & E.coli & $\begin{array}{l}\text { Pseudomonas } \\
\text { aeruginosa }\end{array}$ & $\begin{array}{l}\text { Klebsiella } \\
\text { pneumoniae }\end{array}$ & $\begin{array}{l}\text { Serratia } \\
\text { marcescens }\end{array}$ & $\begin{array}{l}\text { Salmonella } \\
\text { sp }\end{array}$ & $\begin{array}{l}\text { Proteus } \\
\text { sp }\end{array}$ & $\begin{array}{l}\text { Micrococcus } \\
\text { sp }\end{array}$ & $\begin{array}{l}\text { Bacillus } \\
\text { sp }\end{array}$ \\
\hline$C_{1}$ & $11.8 \pm 0.2$ & $11.57 \pm 0.2$ & - & - & - & - & - & - & - & $\begin{array}{l}11.98 \pm \\
0.1\end{array}$ \\
\hline $\mathrm{C}_{2}$ & - & - & - & $11.67 \pm 0.1$ & - & $10.41 \pm 0.3$ & - & $\begin{array}{l}10.67 \\
\pm 0.1\end{array}$ & $11.20 \pm 0.4$ & - \\
\hline$C_{3}$ & $11.50 \pm 0.2$ & $11.34 \pm 0.1$ & $\begin{array}{l}11.50 \\
\pm 0.1\end{array}$ & $10.92 \pm 0.3$ & $10.75 \pm 0.3$ & $10.92 \pm 0.2$ & $11.25 \pm 0.2$ & - & $10.34 \pm 0.1$ & $\begin{array}{l}11.86 \pm \\
0.2\end{array}$ \\
\hline $\mathrm{C}_{4}$ & $10.54 \pm 0.1$ & - & - & $10.79 \pm 0.2$ & - & - & - & - & - & - \\
\hline$Y_{1}$ & - & - & $\begin{array}{l}11.73 \\
\pm 0.2\end{array}$ & - & $11.84 \pm 0.4$ & - & - & - & $11.19 \pm 0.3$ & $\begin{array}{l}10.67 \pm \\
0.2\end{array}$ \\
\hline$Y_{2}$ & - & - & - & - & - & - & - & $\begin{array}{l}10.87 \\
\pm 0.1\end{array}$ & - & - \\
\hline$Y_{3}$ & - & - & - & - & - & $10.97 \pm 0.1$ & - & $\begin{array}{l}11.30 \\
\pm 0.2\end{array}$ & $10.61 \pm 0.2$ & $\begin{array}{l}11.35 \pm \\
0.3\end{array}$ \\
\hline $\mathrm{Y}_{4}$ & - & - & $\begin{array}{l}12.80 \\
\pm 0.1\end{array}$ & $12.05 \pm 0.2$ & - & - & - & $\begin{array}{l}13.38 \\
\pm 0.3\end{array}$ & - & - \\
\hline$Y_{5}$ & $12.27 \pm 0.2$ & - & - & $10.75 \pm 0.4$ & $11.62 \pm 0.2$ & - & $10.59 \pm 0.3$ & $\begin{array}{l}11.65 \\
\pm 0.1\end{array}$ & - & $\begin{array}{l}10.45 \pm \\
0.2\end{array}$ \\
\hline $\mathrm{R}_{1}$ & - & - & $\begin{array}{l}12.16 \\
\pm 0.1\end{array}$ & - & $11.52 \pm 0.1$ & - & - & $\begin{array}{l}11.88 \\
\pm 0.2\end{array}$ & $12.07 \pm 0.1$ & $\begin{array}{l}11.50 \pm \\
0.2\end{array}$ \\
\hline $\mathrm{R}_{2}$ & $10.93 \pm 0.1$ & - & $\begin{array}{l}11.16 \\
\pm 0.2\end{array}$ & - & - & $10.81 \pm 0.1$ & - & $\begin{array}{l}11.27 \\
\pm 0.1\end{array}$ & $10.81 \pm 0.1$ & $\begin{array}{l}10.61 \pm \\
0.2\end{array}$ \\
\hline $\mathrm{R}_{3}$ & $12.97 \pm 0.3$ & $11.69 \pm 0.2$ & $\begin{array}{l}12.14 \\
\pm 0.2\end{array}$ & $12.00 \pm 0.1$ & - & - & - & - & $14.01 \pm 0.2$ & - \\
\hline $\mathrm{R}_{4}$ & - & - & $\begin{array}{l}11.32 \\
\pm 0.2\end{array}$ & - & - & - & - & - & - & - \\
\hline$R_{5}$ & - & - & $\begin{array}{l}10.90 \\
\pm 0.1\end{array}$ & - & $13.43 \pm 0.2$ & - & - & $\begin{array}{l}14.40 \\
\pm 0.1\end{array}$ & $11.26 \pm 0.1$ & - \\
\hline$D_{1}$ & $11.11 \pm 0.2$ & $13.87 \pm 0.2$ & - & - & $10.57 \pm 0.2$ & $15.52 \pm 0.3$ & - & - & $15.13 \pm 0.4$ & - \\
\hline $\mathrm{D}_{2}$ & - & - & $\begin{array}{l}11.40 \\
\pm 0.2\end{array}$ & - & - & - & - & $\begin{array}{l}10.64 \\
\pm 0.1\end{array}$ & - & - \\
\hline$D_{3}$ & $11.41 \pm 0.2$ & - & - & - & - & - & $13.09 \pm 0.1$ & $\begin{array}{l}11.49 \\
\pm 0.2\end{array}$ & - & - \\
\hline $\mathrm{D}_{4}$ & - & - & - & $10.92 \pm 0.3$ & - & - & $12.73 \pm 0.4$ & $\begin{array}{l}10.79 \\
\pm 0.1\end{array}$ & $11.62 \pm 0.1$ & - \\
\hline$D_{5}$ & - & - & - & - & - & - & $10.66 \pm 0.2$ & - & $11.78 \pm 0.1$ & - \\
\hline$D_{6}$ & - & - & - & - & - & - & $10.50 \pm 0.1$ & $\begin{array}{l}10.92 \\
\pm 0.1\end{array}$ & $11.22 \pm 0.4$ & - \\
\hline$I_{1}$ & - & $13.85 \pm 0.2$ & - & - & - & $12.04 \pm 0.1$ & - & - & - & - \\
\hline $\mathrm{I}_{2}$ & - & $11.41 \pm 0.1$ & - & $10.73 \pm 0.4$ & - & - & - & $\begin{array}{l}10.99 \\
\pm 0.1\end{array}$ & - & - \\
\hline $\mathrm{I}_{3}$ & $11.29 \pm 0.2$ & - & - & - & - & - & $11.35 \pm 0.2$ & $\begin{array}{l}11.06 \\
\pm 0.3\end{array}$ & - & - \\
\hline$I_{4}$ & - & - & - & - & - & - & $10.66 \pm 0.1$ & - & $12.14 \pm 0.1$ & - \\
\hline$I_{5}$ & $11.21 \pm 0.1$ & - & - & - & - & - & $10.35 \pm 0.2$ & - & $11.56 \pm 0.4$ & - \\
\hline
\end{tabular}

Clear zones were measured in mm against control. MRS broth was used as control. Results represent the mean \pm standard deviation of three replicates. Here C - strains from curd, Y- strains from yoghurt, I- strains from idli batter, D- strains from dosa batter, R-strains from rice batter.

\section{Physiological characterization of selected bacterial strains}

Physiological characterizations of the selected strains were shown in Table 2. The isolates $\mathrm{C}_{3} \& \mathrm{Y}_{5}$ showed growth at $25^{\circ} \mathrm{C}$ and $45^{\circ} \mathrm{C}$ respectively. But they didn't show any growth at $15^{\circ} \mathrm{C}$ and $55^{\circ} \mathrm{C}$. The isolate $R_{2}$ showed growth at $15^{\circ} \mathrm{C}, 25^{\circ} \mathrm{C}$ and $45^{\circ} \mathrm{C}$. The isolates $C_{3}, R_{2} \& Y_{5}$ did not grow at pH 1.0 and 2.0 . The 
isolate $\mathrm{C}_{3}$ showed growth between $\mathrm{pH} 3.0$ and pH 8.0, while the isolate $\mathrm{R}_{2}$ grew well between $\mathrm{pH} 3.0$ and pH 1.0. The isolate $\mathrm{Y}_{5}$ showed growth between pH ranges 4.0 to 9.0 . All the selected isolates showed growth up to the $12 \% \mathrm{NaCl}$ concentration.

Table 2

Physiological characterization of the selected lactic acid bacterial isolates

\begin{tabular}{|c|c|c|c|}
\hline & $C_{3}$ & $\mathrm{R}_{2}$ & $Y_{5}$ \\
\hline $15^{\circ} \mathrm{C}$ & - & + & - \\
\hline $25^{\circ} \mathrm{C}$ & + & + & + \\
\hline $45^{\circ} \mathrm{C}$ & + & + & + \\
\hline $55^{\circ} \mathrm{C}$ & - & - & - \\
\hline pH 1.0 & - & - & - \\
\hline pH 2.0 & - & - & - \\
\hline pH 3.0 & + & + & - \\
\hline $\mathrm{pH} 4.0$ & + & + & + \\
\hline pH 5.0 & + & + & + \\
\hline pH 6.0 & + & + & + \\
\hline pH 7.0 & + & + & + \\
\hline pH 8.0 & + & + & + \\
\hline pH 9.0 & - & + & + \\
\hline pH 10.0 & - & + & - \\
\hline pH 11.0 & - & - & - \\
\hline $1 \%-4 \% \mathrm{NaCl}$ & + & + & + \\
\hline $4 \%-8 \% \mathrm{NaCl}$ & + & + & + \\
\hline $8 \%-12 \% \mathrm{NaCl}$ & + & + & + \\
\hline $12 \%-16 \% \mathrm{NaCl}$ & - & - & - \\
\hline$+=$ Positive rea & ative & ction & aria \\
\hline
\end{tabular}

\section{Biochemical characterization of selected bacterial strains}

The biochemical characterization of selected bacterial isolates was shown in Table 3. All the selected bacterial isolates didn't show motility and gave negative results for endospore staining.

Similarly all the bacterial isolates were citrate positive and showed negative reaction to gelatin hydrolysis. $\mathrm{R}_{2}$ showed negative reaction to Arginine hydrolysis while $\mathrm{C}_{3}$ and $\mathrm{Y}_{5}$ showed variable reactions (positive and negative response) to Arginine hydrolysis.

Different carbohydrate fermentation patterns observed for selected bacterial isolates were shown in Table 3 . The isolate $\mathrm{C}_{3}$ utilized glucose, sucrose, lactose, galactose, fructose, xylose, maltose, mannose, arabinose and ribose, showed positive and negative response to sorbitol and mannitol and didn't utilize starch and raffinose.

The isolate $\mathrm{R}_{2}$ utilized glucose, sucrose, lactose, galactose, sorbitol, fructose, xylose, maltose, raffinose, mannitol, mannose and ribose, didn't hydrolyze starch and arabinose. The isolate $Y_{5}$ utilized glucose, sucrose, lactose, galactose, fructose, maltose and mannose, didn't utilize sorbitol, xylose, starch, raffinose, arabinose, mannitol and mannose. 
Table 3

Biochemical characterization of the selected bacterial isolates

\begin{tabular}{|c|c|c|c|}
\hline Biochemical feature & $\mathrm{C}_{3}$ & $\mathbf{R}_{\mathbf{2}}$ & $Y_{5}$ \\
\hline Gram staining & + & + & + \\
\hline Endospore staining & - & - & - \\
\hline Motile & Non motile & Non motile & Non motile \\
\hline Catalase test & - & - & - \\
\hline Citrate utilization & + & + & + \\
\hline Gelatin hydrolysis & - & - & - \\
\hline Arginine hydrolysis & v & - & v \\
\hline Gas from glucose & + & + & - \\
\hline Gas from fructose & + & $+/-$ & - \\
\hline \multicolumn{4}{|c|}{ Carbohydrate fermentation } \\
\hline Glucose & + & + & + \\
\hline Sucrose & + & + & + \\
\hline Lactose & + & + & + \\
\hline Galactose & + & + & + \\
\hline Sorbitol & v & + & - \\
\hline Fructose & + & + & + \\
\hline Xylose & + & + & - \\
\hline Starch & - & - & - \\
\hline Maltose & + & + & + \\
\hline Raffinose & - & + & - \\
\hline Mannose & + & + & + \\
\hline Mannitol & v & + & - \\
\hline Arabinose & + & - & - \\
\hline Ribose & + & + & - \\
\hline
\end{tabular}

\section{Molecular characterization of isolated bacterial strains}

The bacterial species labeled as $\mathrm{C}_{3}$, isolated from curd was identified as Lactobacillus reuteri AF182723. The bacterial species labeled as $\mathrm{R}_{2}$ isolated from rice batter was identified as Lactobacillus rhamnosus AY299488 and the bacterial species labeled as $\mathrm{Y}_{5}$ isolated from yoghurt was identified as Lactobacillus acidophilus AF182726 based on the PCR amplification of the 16S - 23S rRNA ISR and its flanking 23SrRNA, sequencing and BLAST analysis.

\section{Discussion}

Previously published studies indicate the LAB isolated by MRS agar supplemented with bromocresol green and cycloheximide and Gram-positive and catalase-negative isolates were selected for further identifications (Fhoula et al., 2013). Likewise, to identify the lactic acid bacteria in naturally fermented sausages (Kaban and Kaya, 2008) and traditional drinking yoghurt in Khartoum state, Sudan only Gram positive and catatalse negative isolated in MRS agar were selected To identify the LAB from wild fruits and flowers present in Northern Argentina (Ali, 2011) only Gram positive catalase negative cocci and rods were selected as presumptive LAB (Rodriguez et al., 2019). In the present study, Lactobacillus reuteri AF182723 isolated from curd sample showed inhibited activity against nine (Staphylococcus aureus, Enterococcus faecalis, E. coli, Pseudomonas aeruginosa, Klebsiella pneumonia, Serratia marcescens, Salmonella sp, Micrococcus sp and Bacillus sp) out of 10 food spoilage organisms tested. Therefore, this isolate Lactobacillus reuteri AF182723 shows the wide spectrum antibacterial activity. Previous studies showed that Lactobacillus bulgaricus and E. faecium exhibited higher wide spectrum antibacterial activity where Lactobacillus bulgaricus showed inhibitory activity against Gram negative bacteria in addition to Gram positive bacteria (Simova, et al., 2009). Bacteriocin from Lactobacillus plantarum had inhibitory activity against many Grampositive and Gram-negative bacteria (Zhou et al., 2014).

Bacteriocins produced by lactic acid bacteria are biologically active proteins or protein complexes displaying a bactericidal mode of action. The one of the techniques use to screen the bacteriocin producing strains is agar well diffusion assay. In the agar well diffusion method supernatants from bacteriocin- 
producing LAB cultures are placed in wells cut into the agar inoculated with an indicator microorganism. Appearance of clear zone around well can be considered as positive signal for the bacteriocin production (Vuyst and Vandamme, 1994).

Many researchers and reviewers found that bacteriocin produced by LAB inhibited the growth of large genera of Gram-positive bacteria (Cleveland et al., 2011, Mokoena, 2017). There are few evidences available for the inhibitory action of LAB on Gram negative bacteria (Smaoui et al., 2010). Therefore, bacteriocin from Lactobacillus reuteri AF182723 would be a novel bacteriocin.

Among the lactic acid bacteria isolated from fermented traditional Raib milk manufactured without starter cultures, Streptococcus thermophilus T2 strain showed wide inhibitory spectrum against the Gram-positive bacteria (Mezaini et al., 2009). Previously published work reported Enterococcus faecalis, Pediococcus pentosaceus and Lactobacillus murinus as strongest bacteriocin producers (Elhag et al., 2015). The predominant antibacterial-producing species were identified as Lactobacillus salivarius, Lactobacillus gasseri, Lactobacillus acidophilus, Lactobacillus crispatus and Enterococcus sp among the intestinal microbiota of elderly Irish subjects (Lakshminarayanan et al., 2013).

Previously published study indicates Lactobacillus reuteri and Lactobacillus rhamnosus showed growth at $15^{\circ} \mathrm{C}$ and $45^{\circ} \mathrm{C}$. Lactobacillus acidophilus didn't show growth at the above temperature (Mithun et al., 2015). Lactobacillus reuteri and Lactobacillus acidophilus didn't grow at $15^{\circ} \mathrm{C}$, but showed growth at $45^{\circ} \mathrm{C}$. Lactobacillus rhamnosus showed growth at $15^{\circ} \mathrm{C}$, but didn't grow at $45^{\circ} \mathrm{C}$ (Vos et al., 2009). More or less similar observations were obtained from this study. The reason for the variation is due to different strains of particular species show different results (Vos et al., 2009).

The previously published study reveals Lactobacillus acidophilus and Lactobacillus rhamnosus grew at pH 6.5 and didn't grow at pH 9.6. The Lactobacillus acidophilus showed growth at $\mathrm{NaCl}$ concentration of $6.5 \%$ and didn't show growth at $\mathrm{NaCl}$ concentration of $9.6 \%$. The Lactobacillus rhamnosus showed growth at $4 \% \mathrm{NaCl}$ concentration and didn't show growth at $\mathrm{NaCl}$ concentration of 6.5 and 9.6. (Mourad et al., 2015).

Based on the gas production in the glucose and fructose medium, the Lactobacillus acidophilus AF182726 is homofermentative lactic acid bacteria and Lactobacillus reuteri AF182723 \& Lactobacillus rhamnosus AY299488 are facultatively heterofermentative lactic acid bacteria. Previously published study reveals Lactobacillus reuteri is obligate heterofermentative bacteria, does not grow at $15^{\circ} \mathrm{C}$ but grows at $45^{\circ} \mathrm{C}$ (Ibrahim, 2016). Previously published study showed Lactobacillus acidophilus grows in acidic and neutral environment, the pH values in the range of 4.0 to 7.0 (Pyar and Peh, 2014). The isolated Lactobacillus acidophilus from Dahi grows at $42^{\circ} \mathrm{C}$ but not grow at $10^{\circ} \mathrm{C}$ (Kavitha et al., 2016). Controversy Lactobacillus acidophilus isolated from Dahi didn't grow at $42^{\circ} \mathrm{C}$ but showed growth at $10^{\circ} \mathrm{C}$ (Bhardwaj et al., 2012).

Published research study found that the Lactobacillus rhamnosus showed growth at $10^{\circ} \mathrm{C}$ and $42^{\circ} \mathrm{C}$ and showed growth up to the $\mathrm{NaCl}$ concentration of $4 \%$ (Bhardwaj et al., 2012). Lactobacillus acidophilus showed growth at $37^{\circ} \mathrm{C}$, but didn't grow at $15^{\circ} \mathrm{C}$ and $45^{\circ} \mathrm{C}$. But Lactobacillus rhamnosus showed growth at $15^{\circ} \mathrm{C}, 37^{\circ} \mathrm{C}$ and $45^{\circ} \mathrm{C}$ (Ahirwar et al., 2017).

Mithun et al., 2015 showed that Lactobacillus reuteri is able to ferment/ utilize the arabinose, melibiose, ribose, lactose and xylose, Lactobacillus rhamnosus able to utilize cellobiose, mannitol, mannose, salicin, lactose, sorbitol, melezitose, sorbitol, xylose and trehalose and Lactobacillus acidophilus able to utilize arabinose, cellobiose, mannitol, mannose, salicin, lactose, melezitose, xylose and trehalose (Mithun et al., 2015).

The isolated $90 \%$ or more strains of Lactobacillus rhamnosus showed positive response to mannitol, ribose, sorbitol and sucrose fermentation. The isolated $90 \%$ or more strains of Lactobacillus rhamnosus showed negative response to arabinose; raffinose and xylose fermentation (Vos et al., 2009). The previously published study reveals the Lactobacillus acidophilus didn't produce $\mathrm{CO}_{2}$ from glucose and $\mathrm{NH}_{3}$ from arginine and utilized mannitol, raffinose, maltose, lactose and galactose and didn't utilize arabinose and sorbitol (Nikita and Hemangi, 2012).

\section{Conclusion}

From this study, the Lactobacillus reuteri AF182723 that was isolated from the curd sample exhibited a wide spectrum antibacterial activity. Therefore bacteriocin isolated from Lactobacillus reuteri AF182723 could be incorporated in the food preparations in order to inhibit the food spoilage organisms .other than Lactobacillus reuteri AF182723, Lactobacillus rhamnosus AY299488 isolated from rice batter and Lactobacillus acidophilus AF182726 isolated from yoghurt also exhibited wide spectrum activity among the isolates tested.

\section{Methods}

\section{Isolation of lactic acid bacteria from fermented food products}

Lactic acid bacteria were isolated from yoghurt, curd, dosa batter, idli batter and soaked and ground rice batter by weighing $1 \mathrm{~g}$ of sample and serially diluted with $0.85 \% \mathrm{NaCl}$. After homogenization, $10^{-2}$ serial dilution of samples were spread on MRS agar medium substituted with bromocresol green ( $\left.0.04 \mathrm{~g} / \mathrm{l}\right)$ and incubated at room temperature $\left(30 \pm 2^{\circ} \mathrm{C}\right)$ for $24-72 \mathrm{~h}$ aerobically and an aerobically. For anaerobic incubation anaerobic jar was used. Randomly picked colonies with yellow colour zone were streaked repeatedly on MRS agar and incubated at room temperature $\left(30 \pm 2^{\circ} \mathrm{C}\right)$ for $24 \mathrm{~h}$ to obtain pure colonies. Isolated pure colonies were streaked on MRS agar substituted with $1 \%$ cycloheximide to check present of yeast among isolates (Yelnetty et al 2014). The isolated pure colonies were stored in MRS agar slant for further studies. Gram staining test was performed to all the isolated colonies. Gram positive colonies were selected to perform antibacterial activity assay.

\section{Detection of antibacterial activity of lactic acid bacteria}


Single colony from the selected bacterial culture by MRS agar containing bromocresol green substituted with $1 \%$ cycloheximide was incubated at room temperature $\left(30 \pm 2^{\circ} \mathrm{C}\right)$ for $24 \mathrm{~h}$ in MRS broth for fermentation. After fermentation, broth was centrifuged at $13000 \mathrm{rpm}$ for $15 \mathrm{~min}$. and supernatant was collected and filtered through $0.45 \mu \mathrm{m}$ syringe filter. Resulted supernatant was assayed for detection of antibacterial activity against food spoilage organisms. The culture of those food spoilage organisms were obtained from Faculty of Science, University of Jaffna, Sri Lanka. Food spoilage organisms (Staphylococcus aureus, Enterococcus faecalis, E.coli, Pseudomonas aeruginosa, Klebsiella pneumoniae, Serratia

marcescens, Salmonella sp., Proteus sp., Micrococcus sp., and Bacillus sp.,) were streaked on the nutrient agar and incubated at $37^{\circ} \mathrm{C}$ for 24 hours. Inocula size of food spoilage organism was adjusted by using heamocytometer at $6.0 \times 10^{8} \mathrm{cfu} / \mathrm{ml} .100 \mu \mathrm{l}$ of the $24 \mathrm{~h}$ old culture suspension of $6.0 \times 10^{8} \mathrm{cfu} / \mathrm{ml}$ indicator strains were mixed with $5 \mathrm{ml}$ of nutrient agar earlier cooled to $47^{\circ} \mathrm{C}$ and then poured onto already solidified nutrient agar ( $10 \mathrm{ml}$ ) plates and allowed to solidify. After solidification, $10 \mathrm{~mm}$ wells were cut by using sterile cork borer. The $100 \mu \mathrm{l}$ of crude supernatants were added to the wells and incubated at $37^{\circ} \mathrm{C}$ for 24 hours. Diameter of clear zone around the well was measured by using digital Vernier caliper. The potential bacterium was selected based on wide spectrum inhibition activity.

\section{Physiological characterization of selected bacterial strains}

\section{Temperature tolerance test}

Abilities of the selected strains at different temperature range from $15^{\circ} \mathrm{C}$ to $55^{\circ} \mathrm{C}$ were evaluated. Selected strains were inoculated into nutrient broth and kept at different temperature. Turbidity was observed after 5 days.

\section{$\mathrm{pH}$ tolerance test}

Nutrient broth was prepared at $\mathrm{pH}$ values $1,2,3,4,5,6,7,8,9,10$, and 11 . Twenty four hours old bacteria cultures were inoculated into respective nutrient broth in test tubes and incubated at $37^{\circ} \mathrm{C}$ for 5 days. Nutrient broth without inoculum was used as control. Turbidity of the nutrient broth after 5 days was observed with control.

\section{$\mathrm{NaCl}$ tolerance test}

Nutrient broth substituted with different concentration of $\mathrm{NaCl}$ ranging from $1 \%-16 \%$ was prepared. 24 hours old bacteria cultures were inoculated into respective nutrient broth in test tubes and incubated at $37^{\circ} \mathrm{C}$ for 5 days. Nutrient broth with different $\mathrm{NaCl}$ concentration without inoculum was used as control. Results were obtained by observing turbidity of nutrient broth after 5 days and compared with control.

\section{Bile tolerance test}

Abilities of the selected strains to tolerance for different bile concentration such as $0.3 \%, 0.5 \%$ and $0.8 \%$ were investigated by inoculate $200 \mu \mathrm{l}$ of $24 \mathrm{~h}$ old $1.5 \times 10^{8} \mathrm{cfu} / \mathrm{ml}$ of inoculum of each isolate into the nutrient broth substituted with different concentration of bile. Inoculated medium was incubated at $37^{\circ} \mathrm{C}$ for 5 days and turbidity was observed.

\section{Biochemical characterization of selected bacterial strains}

Selected strain was subjected to gram staining, catalase test, motility test (hanging drop technique) and endospore staining initially.

\section{Gas production from glucose and fructose}

Ability of strains to produce gas was evaluated by inverting Durham tube into test medium. Test medium was prepared by incorporating sugar (5g/l), peptone $(10 \mathrm{~g} / \mathrm{l})$ and $\mathrm{NaCl}(5 \mathrm{~g} / \mathrm{l})$ and phenol red $(0.018 \mathrm{~g} / \mathrm{l})$ at $\mathrm{pH} 7.0$.

\section{Fermentation of different carbohydrate}

Acid production of strains from various carbon sources namely arabinose,fructose, galactose, glucose, lactose, maltose, mannitol, mannose, raffinose, ribose,sorbitol, starch, sucrose and xylose were investigated. The medium with different sugar was prepared by incorporating sugar $(5 \mathrm{~g} / \mathrm{l})$, peptone (10 $\mathrm{g} / \mathrm{l})$ and $\mathrm{NaCl}(5 \mathrm{~g} / \mathrm{l})$ and phenol red $(0.018 \mathrm{~g} / \mathrm{l})$ at $\mathrm{pH} 7.0$.

\section{Arginine Dihydrolase test (ADH)}

$\mathrm{ADH}$ test medium was prepared by incorporating peptone (1g/l), $\mathrm{NaCl}(5 \mathrm{~g} / \mathrm{l}), \mathrm{K}_{2} \mathrm{H}_{2} \mathrm{PO}_{4}(0.3 \mathrm{~g} / \mathrm{l})$, Arginine $(10 \mathrm{~g} / \mathrm{l})$ and bromocresol purple $(0.016 \mathrm{~g} / \mathrm{l})$ and $\mathrm{pH}$ was adjusted to 6.2 . Selected strains were inoculated into each tubes incubated at $37^{\circ} \mathrm{C}$ for 5 days. Uninoculated test tube with medium was considered as negative control. Colour changes of medium were observed at every day up to 5 days.

\section{Gelatin hydrolysis test}

Gelatin hydrolysis test medium was prepared by incorporating peptone $(5 \mathrm{~g} / \mathrm{l})$, beef extract $(3 \mathrm{~g} / \mathrm{l})$ and gelatin $(120 \mathrm{~g} / \mathrm{l})$ and $\mathrm{pH}$ was adjusted to 6.8 .

\section{Citrate utilization test}

Citrate utilization medium was prepared with composition of sodium citrate $(2 \mathrm{~g} / \mathrm{l}), \mathrm{MgSO}_{4}(0.2 \mathrm{~g} / \mathrm{l})$, ammonium dihydrogen phosphate $(1 \mathrm{~g} / \mathrm{l})$, dipotassium phosphate $(1 \mathrm{~g} / \mathrm{l})$, sodium chloride $(5 \mathrm{~g} / \mathrm{l})$, bromothymol blue $(0.080 \mathrm{~g} / \mathrm{l})$ and Agar $(15 \mathrm{~g} / \mathrm{l})$ and $\mathrm{pH}$ was adjusted to 6.8 . 
Molecular characterization of isolated bacterial strains

Bacterial DNA was extracted by Wizard $®$ Genomic DNA Purification Kit and quantified by Quantus Flurometer. DNA region of 16S, 23S rRNA ISR and its

flanking 23S rRNA was PCR amplified and sequenced.

\section{Declarations}

\section{Ethics approval and consent to participate}

Not applicable

\section{Consent for publication}

All authors agreed to publish this article.

\section{Availability of data and materials}

The data sets used and/or analyzed during the current study are available from the corresponding author on reasonable request.

\section{Competing interests}

The authors declare that they have no competing interests

\section{Funding}

Authors sincerely express their gratitude to National Research Council (NRC) of Sri Lanka for their research grant NRC 16/071.

\section{Authors' contributions}

KS contributed by doing all the experiments involved in the writing up of the manuscript. RK directly supervised the research while SV co-supervised. RK and SV obtained the NRC research grant. All authors read and approved the final manuscript.

\section{Acknowledgements}

Not applicable

\section{References}

1. Ahirwar SS, Gupta MK, Gupta G, Singh V. Screening, isolation and identification of Lactobacillus species from dental caries of children. Int J Curr Microbiol App Sci. 2017; 6(1):497-503.

2. Ali AA, Isolation and identification of lactic acid bacteria isolated from traditional drinking yoghurt in Khartoum state, Sudan. Current research in biotechnology. 2011; 4(1):16-22.

3. Bhardwaj A, Puniya M, Sangu KPS, Sanjay Kumar S, Dhewa T. Isolation and Biochemical Characterization of Lactobacillus species, Isolated from Dahi. A Journal of Dairy Science and Technology. 2012; 1(2):1-12.

4. Cleveland J, Montville TJ, Nes IF, Chikindas ML. Bacteriocins: safe, natural antimicrobials for food preservation. International Journal of Food Microbiology. 2011; 71:1-20.

5. Elhag NB, El Rakha B, Mahdi AA. Isolation and characterization of bacteriocin-producing lactic acid bacteria against indicator organisms. JAAS Journal, $2015 ; 3(1): 6-13$.

6. Fhoula I, Najjari A, Turki Y, Jaballah S, Boudabous A, Ouzari, H. Diversity and antimicrobial properties of lactic acid bacteria isolated from rhizosphere of olive tree and desert truffles of Tunisia. Biomed research international, 2013(4):1-14.

7. Ibrahim SA. Lactic Acid Bacteria: Lactobacillus spp.: Other Species. 2016.

8. Kaban G, Kaya M. Identification of lactic acid bacteria and Gram positive catalase positive cocci isolated from naturally fermented sausage (Sucuk). Journal of food science. 2008; 73(8):385-387.

9. Kavitha P, Sindhuja D, Banumathi M. Isolation and Biochemical Characterization of Lactobacillus species Isolated from Dahi. Int.J.Curr.Microbiol.App.Sci. 2016; 5(4): 1042-1049.

10. Lakshminarayanan B, Guinane CM, O'Connor PM, Coakley M, Hill C, Stanton C, O'Toole PW, Ross RP. 2013. Isolation and characterization of bacteriocinproducing bacteria from the intestinal microbiota of elderly Irish subjects. Journal of applied microbiology. 2013; 114(3):886-898.

11. Mezaini A, Chihib N E, Dilmi Bouras A, Nedjar-Arroume N, Hornez JP. Antibacterial activity of some lactic acid bacteria isolated from an Algerian dairy product. Journal of environmental and public health. 2009.

12. Mithun S, Dipak V, Sheela S. (2015). Isolation and Identification of lactobacilli from raw milk samples obtained from Aarey Milk Colony. International Journal of Scientific and Research Publications. 2015; 5(4): 1-5.

13. Mokoena MP. Lactic acid bacteria and their bacteriocins: Classification, biosynthesis and applications against uropathogens: A mini review. Molecules. 2017; 22(8):1-12. 
14. Mourad G, Bettache G, Samir M, Omrane T. Technological and biochemical characterization of lactic acid bacteria isolated from Algerian traditional dairy products. World applied science journal. 2015; 33(2): 234-241.

15. Nikita C, Hemangi D. Isolation, identification and characterization of lactic acid bacteria from dairy sludge sample. Journal of Environmental Research and Development. 2012; 7(1A):234-244.

16. Pyar H, Peh KK. Characterization and identification of Lactobacillus acidophilus using biolog rapid identification system. Int J Pharm Pharm Sci. 2014; 6(1):189-193.

17. Rodriguez LGR, Mohamed F, Bleckewdel J, Medina R, Vuyst LD, Hebert EM., Mozzi F. Diversity and functional properties of lactic acid bacteria isolated from wild fruits and flowers present in Northern Argentina. Frontiers in microbiology. 2019; 10(1091):1-26.

18. Simova ED, Beshkova DB, Dimtrov ZhP. Characterization and antimicrobial spectrum of bacteriocins produced by lactic acid bacteria isolated from traditional Bulgarian dairy products. Journal of Applied Microbiology. 2009; 10(6):692-701.

19. Smaoui S, Elleuch L, Bejar W, Karray-Rebai I, Ayadi I, Jaouadi B, Mathieu F, Chouayekh H, Bejar S, Mellouli L. Inhibition of fungi and gram-negative bacteria by bacteriocin BacTN635 produced by Lactobacillus plantarum sp. TN635. Applied Biochemistry and Biotechnology. 2010; 162(4):1132-1146.

20. Vos PD, Garrity GM, Jones D, Krieg NP, Ludwig W, Rainey FA, Schleifer K, Whiteman WB. Bergey's manual of systemic bacteriology. Second edition. Springer Dordrecht Heidelberg London New York. 2009; pp 1-1450.

21. Vuyst LD, Leroy F. Bacteriocins from Lactic Acid Bacteria: Production, Purification, and Food Applications. Journal of Molecular Microbiology and Biotechnology. 2007; 13:194-199.

22. Vuyst LD, Vandamme EJ. Bacteriocins of lactic acid bacteria microbiology, genetics and Applications. Blackie Academic \& Professional. London.1994.

23. Yelnetty A, Purnomo H, Purwadi, Mirah A. Biochemical Characteristics of Lactic Acid Bacteria with Proteolytic Activity and Capability as Starter Culture Isolated from Spontaneous Fermented Local Goat Milk. Journal of Natural Sciences Research, 2014; 4(10):137-146.

24. Zacharof MP, Lovittb RW. Bacteriocins Produced by Lactic Acid Bacteria A Review Article. APCBEE Procedia. $2012 ; 2: 50$ - 56.

25. Zhou F, Zhao H, Bai F, Dziugan P, Liu Y, Zhang B. Purification and Characterization of the Bacteriocin Produced by Lactobacillus plantarum, Isolated from Chinese Pickle. Czech J. Food Sci. 2014; 32 (5): 430-436. 